\title{
Spontaneous Pneumomediastinum in a Critically Ill Patient with Influenza A (H1N1) Virus
}

\author{
Faten May®, Héla Maamouri®, Christophe Henry®
}

Service de Réanimation Polyvalente, Centre Hospitalier d'Albi, France

\begin{abstract}
A 43-year-old man who was a non-smoker was referred to the Department of Pulmonary Medicine with 8-day history of fever, dry cough, and symptoms of an acute lower respiratory tract infection. His past medical history, two years earlier, was unremarkable except for pneumonia. There was no prior history of autoimmune diseases or immunosuppressant use. He was examined by a general practitioner, who prescribed antibiotics (amoxicillin-clavulanic acid) and symptomatic treatment, which turned out to be ineffective. Examination revealed acute respiratory failure $\left(\mathrm{SpO}_{2}, 92 \%\right.$ on $6 \mathrm{~L} / \mathrm{min} \mathrm{O}_{2}$ mask). Discrete subcutaneous emphysema was palpated above the left clavicle. Chest radiography showed opacities in bilateral lung fields with a paracardiac air stripe (Figure 1A). Chest computed tomography scan demonstrated a large pneumomediastinum involving the left pectoral area and bilateral ground-glass opacities in both lungs, with greater severity in the left lung (Figure 1B). The patient's clinical status rapidly worsened with the development
\end{abstract}

of acute respiratory distress syndrome. He was transferred to the intensive care unit and placed on immediate mechanical ventilation for 8 days. The nasopharyngeal swab, tested by standard reverse transcription-polymerase chain reaction (PCR) and FILMARRAYTM multiplex PCR system, showed positive result for influenza virus A H1N1 and excluded many other respiratory pathogens. Blood culture did not show any bacterial pathogens. Serum human immunodeficiency virus antibody tests were negative. The patient was treated with oral oseltamivir for 10 days. Empiric intravenous antibiotic therapy with piperacillin-tazobactam and rovamycin was administered and was discontinued after 5 days when microbiological results were negative. On the fifth admission day, subcutaneous emphysema and pneumomediastinum resolved spontaneously without the need for further intervention. By day 13 after admission, the patient had fully recovered and was transferred to the medical ward. At 2 weeks after hospital discharge, the patient was doing well without
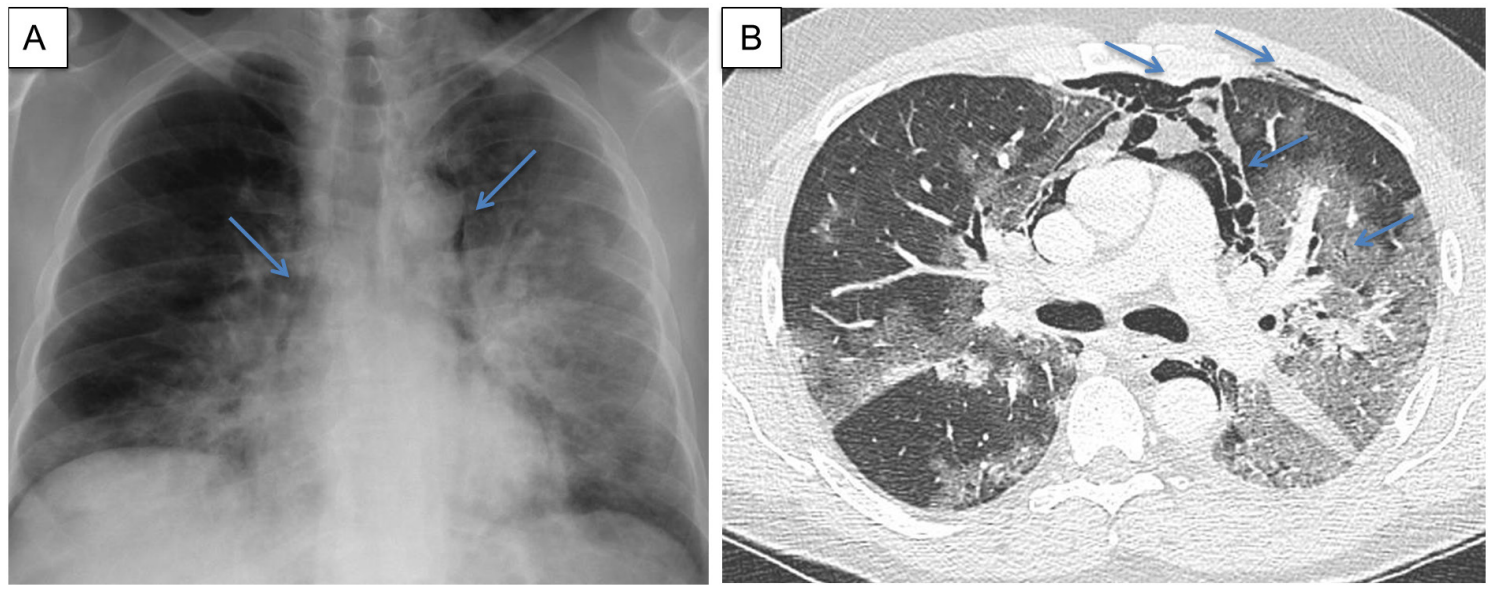

FIG. 1. A, B. (A) Chest radiography showing bilateral opacities with left lung predominance and a paracardiac air stripe (arrows). (B) Axial computed tomography through the middle chest, viewed at lung windows, showing bilateral ground-glass opacities in both lungs, with greater severity in the left lung, subcutaneous emphysema, and pneumomediastinum involving the left pectoral area (arrows).

Address for Correspondence: Faten May, Service de Réanimation Polyvalente, Centre Hospitalier d'Albi, France

e-mail: mayfaten68@gmail.com

Received: July 11, 2020 Accepted: February 5, 2021 •DOI: 10.5152/balkanmedj.2021.20061

Available at www.balkanmedicaljournal.org

ORCID iDs of the authors: F.M. 0000-0002-2894-5212; H.M. 0000-0003-1877-201X; C.H. 0000-0001-5520-1828.

Cite this article as:

May F, Maamouri H, Henry C. Spontaneous pneumomediastinum in a critically ill patient with influenza a (H1N1) virus. Balkan Med J. 2021 ; 38(3):192-193.

Copyright@Author(s) - Available online at http://balkanmedicaljournal.org/ 
respiratory symptoms and follow-up chest radiography showed complete regression of the pneumomediastinum.

Spontaneous pneumomediastinum is an uncommon condition that should be considered as a potential complication in adults with severe influenza A (H1N1) virus infection, ${ }^{1}$ and very few similar cases were reported in the literature. ${ }^{2-4}$ Spontaneous pneumomediastinum generally resolves spontaneously. However, it can result in multiple complications, including pneumothorax, extensive subcutaneous emphysema, and tension pneumomediastinum, which compromise the cardiorespiratory state and require chest drainage. ${ }^{5}$

Patient Consent for Publication: The IRB/Ethics Committee did not require informed consent from the patient to submit this case report because no patient identifiers were presented.

Author Contributions: Concept - F.M.; Design - F.M.; Supervision - C.H.; Materials F.M., H.M.; Data Collection and/or Processing - F.M.; Analysis and/or Interpretation F.M., H.M.; Literature Review - F.M., C.H.; Writing - F.M., H.M.; Critical Review - F.M., H.M
Acknowledgments: The authors would like to express his deep gratitude to Doctor Henry and Doctor Mamouri for their contribution to this project and their constructive suggestions.

Conflict of Interest: The authors have no conflicts of interest to declare.

Funding: The authors declared that this study had received no financial support.

\section{REFERENCES}

1. Patel V, Raval G, Gavadia K. Pneumothorax, pneumomediastinum, subcutaneous emphysema and pneumorrhachis as complications of common flu. Am J Case Rep. 2012;13:198-201. [CrossRef]

2. Luis BAL, Navarro AO, Palacios GMR. Pneumomediastinum and subcutaneous emphysema associated with influenza AH1N1 virus. Lancet Infect Dis. 2017;17(6):671. [CrossRef]

3. Mansbridge CT, Inada-Kim M. Pneumomediastinum associated with influenza A infection. N Engl J Med. 2018;378(1):e1. [CrossRef]

4. Chekkoth SM, Supreeth RN, Valsala N, Kumar P, Raja RS. Spontaneous pneumomediastinum in H1N1 infection: uncommon complication of a common infection. $J R$ Coll Phys Edinb. 2019;49(4):298-300. [CrossRef]

5. Singh BP, Shetty GS, Vijayan PA, et al. Management of pneumomediastinum associated with H1N1 pneumonia: a case report. J Crit Care Med. 2019;5(1):28-33. [CrossRef] 